\title{
Gender differences in work-family conflict and family-friendly employment policy practices
}

\begin{abstract}
Changes in the demographic make-up of the workforce have been the primary impetus for the increased focus on work and family issues. Competing demands, which arise between work and family roles, often result in conflict for employees. Besides the increase in women, dualearner couples, and single parents in the workplace, technological change and the need to be globally competitive increase the pressures on organizations and employees alike. This study examined the work-family conflict experienced by female employees and their husbands, as well as family-friendly employment policy practices in the government and selected private organizations in Malaysia. Two forms of work-family conflict were studied, namely work-tofamily conflict and family-to-work conflict, and gender differences in the experience of the two forms of work-family conflict were compared. Data on work-family conflict were gathered from 1303 employees consisting of 711 married females, aged 45 and below, as well as their husbands who made up 592 of the respondents. These data were gathered using selfadministered questionnaires. Three broad categories of family-friendly facilities were studied including work arrangements, family care benefits, and child care facilities and related benefits. Policy practices in the federal government were examined through document analysis and interviews with human resource personnel. Data from eight private organizations were gathered using questionnaires and interviews with human resource managerial staff. The employees experienced greater work-to-family conflict than family-to-work conflict. An analysis by gender revealed that female employees experienced greater work-to-family than their husbands. However, both female employees and their husbands experienced family-towork conflict in intensities that do not differ significantly. Generally, the government has been more generous than the private organizations studied in terms of providing familyfriendly facilities. Overall, these organizations were still at the early stage of development of policies which could support the reconciliation of the demands of work and family life.
\end{abstract}

Keyword: Work-Family Conflict, Gender, Family-Friendly Employment Policy 